\title{
Establishment and applications of male germ cell and Sertoli cell lines
}

\author{
Hong Wang ${ }^{1, *}$, Liping Wen ${ }^{1, *}$, Qingqing Yuan ${ }^{1, *}$, Min Sun ${ }^{1}$, Minghui Niu ${ }^{1}$ \\ and Zuping $\mathrm{He}^{1,2,3,4}$ \\ 'State Key Laboratory of Oncogenes and Related Genes, Renji-Med X Clinical Stem Cell Research Center, \\ ${ }^{2}$ Shanghai Institute of Andrology, Ren Ji Hospital, School of Medicine, Shanghai Jiao Tong University, \\ Shanghai, China, ${ }^{3}$ Shanghai Key Laboratory of Assisted Reproduction and Reproductive Genetics, \\ Shanghai, China, and ${ }^{4}$ Shanghai Key Laboratory of Reproductive Medicine, Shanghai, China \\ Correspondence should be addressed to Zuping He; Email: zupinghe@sjtu.edu.cn
}

*(H Wang, L Wen and Q Yuan contributed equally to this work)

\begin{abstract}
Within the seminiferous tubules there are two major cell types, namely male germ cells and Sertoli cells. Recent studies have demonstrated that male germ cells and Sertoli cells can have significant applications in treating male infertility and other diseases. However, primary male germ cells are hard to proliferate in vitro and the number of spermatogonial stem cells is scarce. Therefore, methods that promote the expansion of these cell populations are essential for their use from the bench to the bed side. Notably, a number of cell lines for rodent spermatogonia, spermatocytes and Sertoli cells have been developed, and significantly we have successfully established a human spermatogonial stem cell line with an unlimited proliferation potential and no tumor formation. This newly developed cell line could provide an abundant source of cells for uncovering molecular mechanisms underlying human spermatogenesis and for their utilization in the field of reproductive and regenerative medicine. In this review, we discuss the methods for establishing spermatogonial, spermatocyte and Sertoli cell lines using various kinds of approaches, including spontaneity, transgenic animals with oncogenes, simian virus 40 (SV40) large T antigen, the gene coding for a temperature-sensitive mutant of $p 53$, telomerase reverse gene (Tert), and the specific promoter-based selection strategy. We further highlight the essential applications of these cell lines in basic research and translation medicine.

Reproduction (2016) 152 R31-R40
\end{abstract}

\section{Introduction}

Spermatogenesis is a complex process including the mitosis of spermatogonia, meiosis of spermatocytes and spermiogenesis of spermatids. Infertility affects $10-15 \%$ of couples, of which male infertility contributes to half of the cases (Schlegel 2009). Azoospermia has been observed in $1 \%$ of the general population and it comprises $15 \%$ of male infertility (Wosnitzer et al. 2014). Notably, we have recently demonstrated that human spermatogonial stem cells (SSCs) from cryptorchid patients can be coaxed to differentiate into haploid spermatids with fertilization and developmental capacity (Yang et al. 2014a), suggesting that human SSCs have the significant potential to treat male infertility. Furthermore, SSCs can dedifferentiate to become embryonic stem (ES)-like cells that differentiate into numerous types of cells (Kanatsu-Shinohara et al. 2004, Guan et al. 2006, Seandel et al. 2007, Golestaneh et al. 2009, Ko et al.
2009), and they are able to directly transdifferentiate into the cells of other lineages (Simon et al. 2009, Zhang et al. 2013, Yang et al. 2015). These studies reflect the prospect of SSCs in regenerative medicine to treat human diseases.

As the only type of somatic cell within the seminiferous tubules, Sertoli cells play essential roles in regulating spermatogenesis, including physiological contact and structural, immunological and nutritional support for male germ cells (Hai et al. 2014). Sertoli cells can be reprogrammed to pluripotent stem cells (Sun et al. 2014), and significantly they are directly converted to morphologic, phenotypic and functional neural stem cells (Sheng et al. 2012) and Leydig cells (Zhang et al. 2015). Moreover, Sertoli cells are engineered to produce certain proteins that restore cell metabolic function (Kaur et al. 2014). Therefore, Sertoli cells can be utilized in disease modeling and regenerative medicine. 
It is hard to expand primary male germ cells in vitro, and the number of spermatogonial stem cells is very limited. Thus, it is essential to immortalize male germ cells and Sertoli cells to obtain sufficient cells in order to enlarge their usage from the bench to the bed side. The spontaneous immortalization in nature is extremely uncommon as evidenced by the fact that rodent cells can be spontaneously immortalized with a maximal frequency of $10^{-5}$ and the chance of human cell spontaneous immortalization is less than $10^{-12}$ (Katakura et al. 1998). Several approaches have been used to induce cell immortalization, including overexpression of telomerase reverse transcriptase (Tert), virus (e.g. simian virus 40 (SV40) large $T$ antigen, polyomavirus large $T$ antigen (PyLT), papillomaviruses E6 and E7, adenovirus $\mathrm{E} 1 \mathrm{~A}$, and herpesvirus saimiri), oncogenes (e.g. Myc, Ras, Jun), and tumor suppressor genes ( $p 16, p 53, R b 1)$. Tert has certain advantages over other immortalized genes since immortalized cells by overexpressing Tert retain genomic stability and phenotypic properties of the cells with normal karyotype and growth rate without transformation. Based on recent progress, we address the establishment and characterization of male germ cell and Sertoli cell lines using various kinds of immortalization approaches. We also highlight the potential and significant applications of these cell lines in mechanistic studies and clinic.

\section{Establishment and characterization of Sertoli cell lines with different methods}

In rodents, immature Sertoli cells start to divide at 15 days of age and express immature cell markers, such as anti-Müllerian hormone (Amh), Krt8 (also known as Ck18), and M2A (Blagosklonova et al. 2002, Hai et al. 2014). Subsequently, Sertoli cells begin to differentiate and express mature cell hallmarks, e.g. androgen receptor (AR), and acquire the function of mature Sertoli cells to support spermatogenesis (Regadera et al. 2001).

As illustrated in Fig. 1, a number of rodent Sertoli cell lines have been established by different approaches for comprehensive understanding of the biology and function of Sertoli cells. The phenotypic characteristics of these Sertoli cell lines are summarized in Table 1. There are three categories of markers for Sertoli cells, namely immature, mature and whole-stage markers. As shown in Table 1, immature markers for Sertoli cells include AMH, KRT18 (CK18), M2A and NCAM (Neural cell adhesion molecule) (Blagosklonova et al. 2002, Sharpe et al. 2003, Hai et al. 2014), whereas AR, SGP2

Table 1 The phenotype of primary Sertoli cells and Sertoli cell lines.

\begin{tabular}{|c|c|c|c|c|}
\hline Cell types & Markers & Undetected & Species & References \\
\hline Primary Sertoli cells & $\begin{array}{l}\text { Immature markers: AMH, KRT18, M2A, } \\
\text { NCAM; mature markers: AR, SGP2, GATA1, } \\
\text { p27kip1; whole-stage markers: WT1, GATA4, } \\
\text { SOX9, VIM, GDNF, SCF }\end{array}$ & - & Rats and mice & $\begin{array}{l}\text { Sharpe et al. (2003), } \\
\text { Kanatsu-Shinohara et al. } \\
(2012)\end{array}$ \\
\hline TM4 cell line & $\begin{array}{l}\text { Immature marker: Amh; mature marker: } \\
\text { Sgp2; whole-stage markers: Scf, Sox9, } \\
\text { other markers: Sf1, Dhh }\end{array}$ & Wt1, Sry & 11-day-old mice & $\begin{array}{l}\text { Mather (1980), } \\
\text { Beverdam et al. (2003) }\end{array}$ \\
\hline $\begin{array}{l}\text { A31C4, C22A4, C24A4 } \\
\text { cell lines }\end{array}$ & $\begin{array}{l}\text { Immature marker: Amh; mature markers: } \\
\text { Ar, Sgp2; whole-stage markers: Wt1, Scf, } \\
\text { Sox9; other markers: Tf (transferrin), Fshr, } \\
\text { Ocln (Occludin), Clu (clusterin), Inha (inhibin } \\
\text { alpha), Tgfb, Fgf2 }\end{array}$ & $\begin{array}{l}\text { Shbg (known as } \\
\text { Abp) }\end{array}$ & 6-week-old mice & Sato et al. (2013) \\
\hline 15P-1 cell line & $\begin{array}{l}\text { Whole-stage markers: Wt1, Steel } \\
\text { (ligand for Kit, known as Scf) }\end{array}$ & - & Young mice & $\begin{array}{l}\text { Paquis-Flucklinger et al. } \\
\text { (1993), Rassoulzadegan } \\
\text { et al. (1993) }\end{array}$ \\
\hline SMAT1 cell line & $\begin{array}{l}\text { Immature markers: Amh; mature marker: } \\
\text { Sgp2; whole-stage markers: Wt1, Scf; other } \\
\text { markers: Sf1, Sgp1, Shbg, Inha, Inhb }\end{array}$ & Tf, Fshr & 6.5-day-old mice & Dutertre et al. (1997) \\
\hline ASC-17 cell line & $\begin{array}{l}\text { Immature marker: Krt18; mature marker: } \\
\text { Sgp2; other markers: } T f, \text { Sgp } 1\end{array}$ & Shbg & 120-day-old rats & Roberts et al. (1995) \\
\hline 42GPA9 cell line & $\begin{array}{l}\text { Mature marker: Sgp2; whole-stage marker: } \\
\text { Scf; other markers: Tf, Fshr, Tjp1(Zo1) }\end{array}$ & - & 6-month-old mice & Bourdon et al. (1998) \\
\hline TTE3 cell line & $\begin{array}{l}\text { Mature marker: Sgp2; whole-stage marker: } \\
\text { Scf; other markers: Fshr, Tjp1, Tf, Inha }\end{array}$ & Krt18 & 8-week-old mice & Tabuchi et al. (2002) \\
\hline RTS3-3 cell line & Mature marker: Sgp2; other marker: $T f$ & Fshr & 27-week old rats & Tabuchi et al. (2003) \\
\hline SerW3 cell line & Other marker: $T f$ & - & 17-day-old rats & Pognan et al. (1997) \\
\hline 93RS2 cell line & $\begin{array}{l}\text { Mature marker: Sgp2; whole-stage marker: } \\
\text { Scf; other markers: Tf , Sgp1 }\end{array}$ & $\begin{array}{l}\text { Fshr, Shbg, Gdnf, } \\
\text { Bmp4 }\end{array}$ & 16-day-old rats & Jiang et al. (1997) \\
\hline SCIT-C8 cell line & Whole-stage marker: Scf; other markers: $T f, C l u$ & Ar, Fshr & 19-day-old rats & Konrad et al. (2005) \\
\hline SK11 cell line & $\begin{array}{l}\text { Immature marker: Amh; mature markers: } \\
\text { GATA1, AR and SGP2 induced by hormone } \\
\text { treatment; whole-stage marker: Scf; other } \\
\text { markers: shr, Sf1, Tf, Inha }\end{array}$ & Shbg, Cd68, Lhr & 10-day-old mice & $\begin{array}{l}\text { Sneddon et al. (2005), } \\
\text { Walther et al. (1996) }\end{array}$ \\
\hline $\begin{array}{l}\text { B6SC-2 and B6SC-3 cell } \\
\text { lines }\end{array}$ & $\begin{array}{l}\text { Immature marker: Amh; mature marker: } \\
\text { Gata1; other markers: Fshr, Tjp1, Shbg }\end{array}$ & - & 19-day-old mice & Chuang et al. (2007) \\
\hline
\end{tabular}




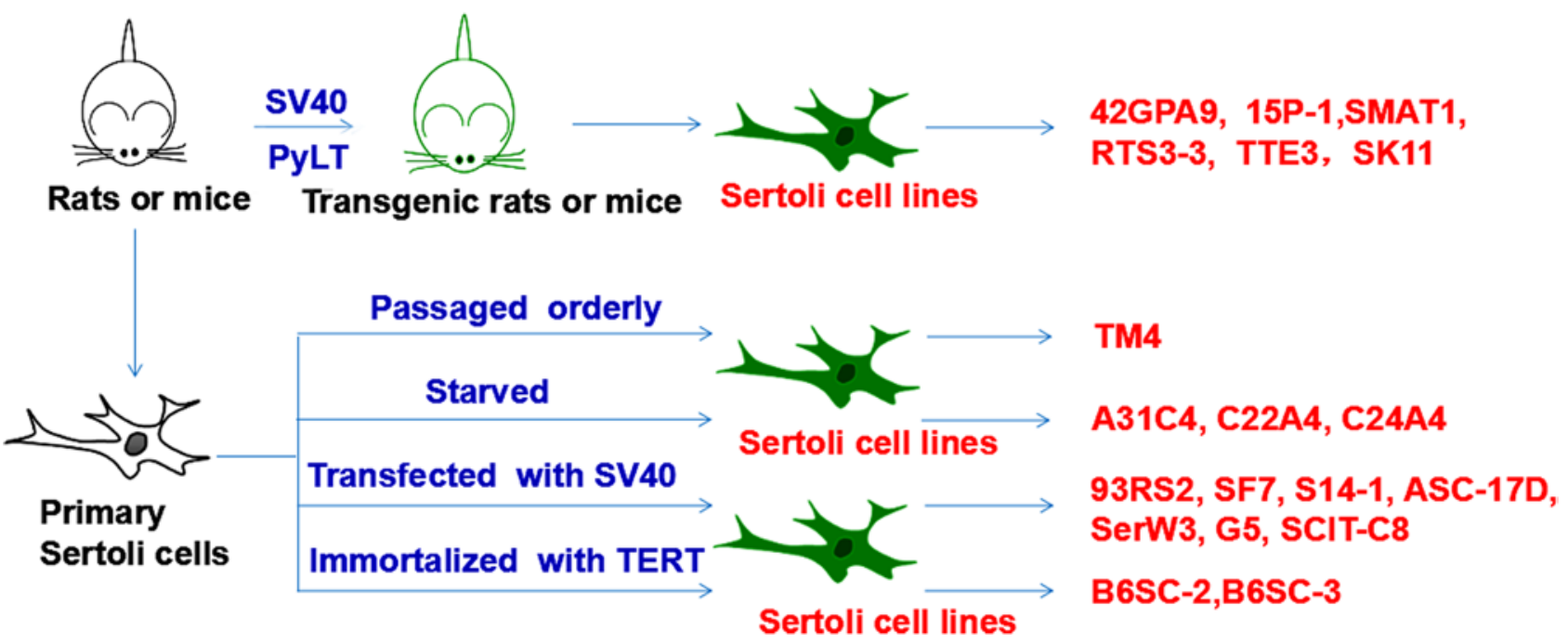

Figure 1 Schematic diagram showing the establishment of Sertoli cell lines. The immortalization methods of rodent Sertoli cell lines include spontaneity, SV40 transgenic animals, transfection with SV40 or Tert, and starvation.

(Sulfated glycoprotein 2), GATA1 and p27 kip1 can be used as mature hallmarks for these cells (Regadera et al. 2001, Sharpe et al. 2003, Sato et al. 2013). In addition, WT1, GATA4, SOX9, VIM, SCF and GDNF serve as whole-stage markers for Sertoli cells.

\section{Establishment of Sertoli cell lines without gene transfection and their characteristics and applications}

TM4 cell line is an earlier Sertoli cell line developed spontaneously without gene transfection (Mather 1980). Sertoli cells were isolated from mouse testes and cultured with certain kinds of substances, such as retinoic acid (RA), luteinizing hormone (LH), follicle-stimulating hormone $(\mathrm{FSH})$, somatomedin $\mathrm{C}$, LH-B10, FSH-S11, $\left[{ }^{3} \mathrm{H}\right]$-progesterone and $\left[{ }^{14} \mathrm{C}\right]$-cholesterol. Eventually, TM4 cell line with Sertoli cell identity was established according to the morphology, metabolism of steroids and the response to insulin, transferrin, epidermal growth factor (EGF), growth hormone, FSH and RA (Mather 1980). TM4 cell line can be cloned several times and cultured for over 2 years. These cells possess epithelial appearance and form contact-inhibition monolayer at confluence. Moreover, no tumor is observed when these cells are injected into nude mice. Since the TM4 cell line was established from immature mice, its properties may be more similar to the cells from prepubertal rodents, which can serve as an excellent model for investigating the division of immature Sertoli cells.

TM4 cell line has been applied in many aspects. Although the function of AR in spermatogenesis is well known, its mechanisms in regulating Sertoli cells remain unclear. TM4 cell line has been used to identify Hsf1 as a novel target of AR in mouse Sertoli cells (Yang et al. 2014b) and CLMP as a new tight junction transmembrane protein (Sze et al. 2008). In addition, this cell line has recently been utilized to elucidate the pharmacological roles and ERK/Akt signaling pathway of diosgenin and offer novel therapeutic methods to treat male infertility (Wu et al. 2015). Starvation method has also been applied to generate three Sertoli cell lines, including A31C4, C22A4 and C24A4 (Sato et al. 2013). Similar to TM4 cell line, these Sertoli cell lines were created without inducing ectogenic oncogenes, and thus their behavior is close to primary Sertoli cells and they can be applied to basic research on the interactions among male germ cells and Sertoli cells. Furthermore, these cell lines without gene transfection are unique cells that express mature Sertoli cell markers (e.g. AR and SGP2) under usual culture condition and can respond properly to $\mathrm{FSH}$.

\section{Establishment of Sertoli cell lines from transgenic animals or by infecting primary Sertoli cells with oncogenes}

Numerous Sertoli cell lines have been immortalized by large $T$ agent (LTAg), PyLT, oncogenes, or from transgenic animals expressing LTAg gene. For example, 42GPA9 and 15P-1 Sertoli cell lines were derived from PyLT transgenic mice (Paquis-Flucklinger et al. 1993, Bourdon et al. 1998). The 42GPA9 cell line possesses the characteristics of mature Sertoli cells since it expresses many markers of primary mature Sertoli cells (e.g. AR), responds to FSH and forms tight junctions (Bourdon et al. 1998). The 15P-1 cell line retains the morphological and functional features of primary Sertoli cells. Both cell lines may be utilized to examine the self-renewal and differentiation of SSCs. SMAT1 cell line has been generated from mice with SV 40 
gene (Dutertre et al. 1997) and its expression pattern is similar to the characteristics of Sertoli cells from prepubertal mice. SMAT1 cell line can produce AMH even at the 37 th passage, suggesting that this cell line might maintain an immature status for a long period. The conditionally immortalized RTS3-3 and TTE3 Sertoli cell lines have been generated from transgenic rats or mice harboring temperature-sensitive simian virus 40 (tsSV40) large T antigen (Tabuchi et al. 2002, Tabuchi et al. 2003). Another Sertoli cell line 93RS2 was established by immortalizing primary rat Sertoli cells with SV40 tsA255 (Jiang et al. 1997). However, this cell line can form tumor although it has normal chromosome. Unlike the primary Sertoli cells, AR and FSHR are undetected in Sertoli cell lines immortalized by LTAg. Some immature Sertoli cell lines (e.g. 93RS2) have no response to $\mathrm{FSH}$, and most of them are unable to produce GDNF or BMP4. On the other hand, almost all of these Sertoli cell lines show epithelial attributes in appearance and have phagocytic activity. Since these cell lines have unique characteristics of Sertoli cells in response to changes of temperature, they can be used to explore the influence of epigenetic environment including temperature on spermatogenesis.

\section{Sertoli cell lines immortalized by human telomerase reverse gene (Tert)}

Two Sertoli cell lines B6Sc-2 and B6Sc-3 have been established from primary Sertoli cells of 19-day-old mice by immortalization with pBK-CMV-Tert (Chuang et al. 2007). These cell lines possess the characteristics of Sertoli cells since they express tyrosine-tubulin, vimentin and stem cell factor (SCF) (Chuang et al. 2007). Moreover, the expression of SCF is maintained in these cell lines for 20 passages, which promotes the proliferation and differentiation of SSCs via the KIT receptor (Sette et al. 2000). The expression of FSHR is also detected in both cell lines, which can respond to FSH and phosphorate a number of proteins. B6Sc-2 cell line and TM4 cell line express similar levels of Sertoli cell-specific genes, including Amh, Cldn11 (also known as claudin11) and Tjp1 (also known as Zo1). Notably, the expression of AR can be induced by tumor necrosis factor-a (TNF-a) in both B6Sc-2 and B6Sc-3 cell lines. The morphology, cytoskeleton distribution, growth rate and phenotype of B6SC-2 and B6SC-3 cell lines are analogous to primary Sertoli cells, and thus they may provide a useful cell source for understanding Sertoli cell biology.

As described above, a number of established rodent Sertoli cell lines have unlimited proliferation potentials and possess biochemical characteristics of primary Sertoli cells. These cell lines can facilitate our understanding of the biology of Sertoli cells and their roles in mediating spermatogenesis. Nevertheless, human Sertoli cell lines are not yet available. Recently, we have shown that human primary Sertoli cells can be cultured for 2 months and expanded with a remarkable increase of cell numbers while retaining their morphology, phenotype and AKT and SMAD1/5 signaling pathways (Guo et al. 2015). This study can provide a basis for establishing a human Sertoli cell line.

\section{The establishment and applications of spermatogonial cell lines}

We illustrate the generation of rodent spermatogonial cell lines in Fig. 2, and the immortalization approaches and phenotype of these cell lines are summarized in Table 2.

\section{Immortalization of rat and human spermatogonial stem cell (SSC) lines with SV40 lager T antigen}

In 2002, rat SSC lines A303 and A304 were established with SV40 large $T$ antigen (van Pelt et al. 2002). The starting cells were $A_{s^{\prime}} A_{p r}$ and $A_{a l}$ spermatogonia, and both cell lines express Hsp90a and Pou5f1 (also known as Oct4), which are markers for germ cells and SSCs (He et al. 2007, 2009); however, these cells are negative for $\mathrm{KIT}$, a hallmark for differentiating $\mathrm{A}_{1}-\mathrm{A}_{4}$ spermatogonia (He et al. 2007). In the in vitro study, these cell lines have been cultured for 3 years and passaged for more than 50 times without morphological or DNA content changes. For the in vivo transplantation, they can migrate to the basement membrane and colonize in the seminiferous tubules of recipient mice, and no tumor formation is observed. The findings indicate that these cell lines possess typical characteristics of primary SSCs, and therefore they could be utilized to unveil the mechanisms regulating self-renewal (proliferation and survival) of rodent SSCs. Since it is unclear if these cell lines can differentiate in the recipient mice, it remains to be defined whether they are suitable to be used to examine the differentiation of rat SSCs.

Most importantly, we have for the first time established a human SSC cell line by stably overexpressing human SV40 large T antigen (Hou et al. 2015). Molecular and cellular analyses reveal that this cell line expresses a number of human spermatogonial and SSC hallmarks, including VASA, DAZL, MAGEA4, GFRA1, RET, UCHL1, GPR125, PLZF and THY1 (Hou et al. 2015), indicating that these cells are human SSCs in phenotype. It is worth noting that this cell line can be cultured for 1.5 years and expanded with a significant increase of cell numbers, while maintaining high levels of PCNA and UCHL1. Moreover, this human SSC line is able to colonize and proliferate in the recipient mice (Hou et al. 2015). Neither $\mathrm{Y}$ chromosome microdeletions of numerous genes nor tumor formation has been observed in human SSC line. Therefore, this human SSC line can provide an adequate source of human SSCs for basic studies and translational medicine. 
Table 2 The establishment and characterization of male germ cell lines.

\begin{tabular}{|c|c|c|c|c|c|c|}
\hline Cell lines & Species & Method & Cell identity & Markers & Differentiation & References \\
\hline $\begin{array}{l}\text { GC- } 1 \text { spg cell } \\
\text { line }\end{array}$ & 10-day-old mice & SV40 & $\begin{array}{l}\text { Type B spermato- } \\
\text { gonia and } \\
\text { preleptotene } \\
\text { spermatocytes }\end{array}$ & Ldhc4 & No differentiation & $\begin{array}{l}\text { Hofmann et al. } \\
\text { (1992) }\end{array}$ \\
\hline $\begin{array}{l}\text { GC-2spd cell } \\
\text { line }\end{array}$ & 6-week-old mice & $\begin{array}{l}\text { SV } 40 \text { and the gene } \\
\text { coding for a } \\
\text { temperature-sensitive } \\
\text { mutant of } p 53\end{array}$ & $\begin{array}{l}\text { Preleptotene } \\
\text { spermatocytes }\end{array}$ & Ldhc4 & $\begin{array}{l}\text { Differentiate into } \\
\text { round spermatids; } \\
\text { cultured with } \\
\text { complete CMRjkiL- } \\
1066 \text { medium }\end{array}$ & $\begin{array}{l}\text { Hofmann et al. } \\
\text { (1994) }\end{array}$ \\
\hline $\begin{array}{l}\text { GC-3spc cell } \\
\text { line }\end{array}$ & 6-week-old mice & $\begin{array}{l}\text { SV40 and the gene } \\
\text { coding for a } \\
\text { temperature-sensitive } \\
\text { mutant of } p 53\end{array}$ & $\begin{array}{l}\text { Preleptotene } \\
\text { spermatocytes }\end{array}$ & Ldhc4 & No differentiation & $\begin{array}{l}\text { Hofmann et al. } \\
\text { (1994) }\end{array}$ \\
\hline $\begin{array}{l}\text { GC- } 4 \text { spc cell } \\
\text { line }\end{array}$ & $\begin{array}{l}\text { Adult transgenic } \\
\text { mice }\end{array}$ & $\begin{array}{l}\text { SV40 and a spermatocyte- } \\
\text { specific promoter for } \\
\text { human PGK2 }\end{array}$ & $\begin{array}{l}\text { Preleptotene and } \\
\text { early pachytene } \\
\text { spermatocytes }\end{array}$ & Pgk2, TSPY & No differentiation & $\begin{array}{l}\text { Tascou et al. } \\
\text { (2000) }\end{array}$ \\
\hline $\begin{array}{l}\text { A303 and A304 } \\
\text { cell lines }\end{array}$ & $\begin{array}{l}\text { Vitamin } \\
\text { A-deficient rats }\end{array}$ & SV40 & $\begin{array}{l}\mathrm{A}_{\mathrm{s}}, \mathrm{A}_{\mathrm{pr}}, \mathrm{A}_{\mathrm{al}} \\
\text { spermatogonia }\end{array}$ & Hsp90, Pou5f1 & No differentiation & $\begin{array}{l}\text { van Pelt et al. } \\
(2002)\end{array}$ \\
\hline C18-4 cell line & 6-day-old mice & SV40 & $\begin{array}{l}\text { Type A } \\
\text { spermatogonia }\end{array}$ & $\begin{array}{l}\text { Dazl, Pou5f1, Gfra1, } \\
\text { Piwil2, Tex13, } \\
\text { Tex14, Tex15, } \\
\text { Tex16, Tex19 }\end{array}$ & No differentiation & $\begin{array}{l}\text { Hofmann et al. } \\
\text { (2005) }\end{array}$ \\
\hline S4 cell line & 6-day-old mice & Tert & $\begin{array}{l}\text { Type A } \\
\text { spermatogonia }\end{array}$ & Dazl, Pou5f1, Kit & $\begin{array}{l}\text { Differentiate into } \\
\text { sperm; cultured in } \\
\text { DMEM with SCF }\end{array}$ & $\begin{array}{l}\text { Feng et al. } \\
\text { (2002) }\end{array}$ \\
\hline Unnamed & Human & SV40 & $\begin{array}{l}\text { Spermatogonial } \\
\text { stem cells }\end{array}$ & $\begin{array}{l}\text { VASA, DAZL, } \\
\text { MAGEA4, GFRA1, } \\
\text { RET, UCHL1, } \\
\text { GPR125, PLZF, } \\
\text { THY1 }\end{array}$ & Not determined & $\begin{array}{l}\text { Hou et al. } \\
\text { (2015) }\end{array}$ \\
\hline
\end{tabular}

\section{Immortalization of mouse type A spermatogonia cell line C18-4 cells with the SV large $T$ antigen gene}

The C18-4 cell line has been established with type A spermatogonia from 6-day-old mice using the SV large T antigen gene under the control of an ecdysone-inducible promoter (Hofmann et al. 2005). After selection with

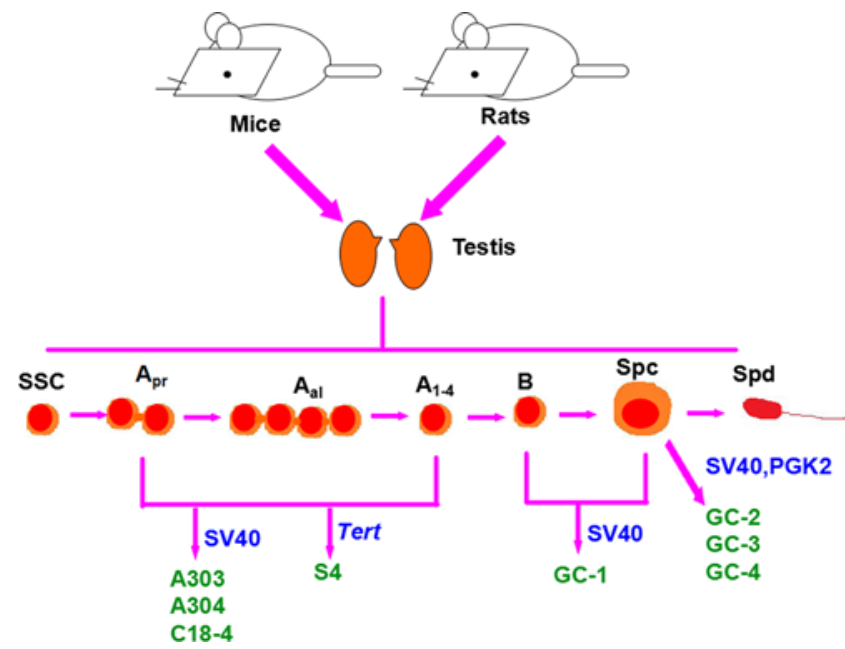

Figure 2 Schematic diagram revealing the establishment of male germ cell lines. SSC, spermatogonial stem cell; $A_{p r}$, type $A$ paired spermatogonia; $A_{a l}$, type $A$ aligned spermatogonia; $A_{1-4}$, type $A_{1-4}$ spermatogonia; B, type B spermatogonia; Spc, spermatocytes; Spd, spermatids; phosphoglycerate kinase 2 (PGK2). antibiotics zeocin and G418, the C18-4 cell line was obtained and its appearance was round or polygonal with a high ratio of nucleus to cytoplasm. Notably, this cell line possesses the phenotype of male germ cells and undifferentiated spermatogonia since it expresses Dazl, Pou5f1, Gfra1, Piwil2, Tex13, Tex14, Tex15, Tex16 and Tex19 (Hofmann et al. 2005); however, C18-4 cell line does not express Kit (a marker for differentiating spermatogonia) (He et al. 2007). Additionally, this cell line responds to GDNF rather than SCF, suggesting that it prefers to proliferate rather than differentiate. The C18-4 cell line has important applications in uncovering the molecular mechanisms of rodent SSCs. As examples, we have used this cell line to demonstrate that GDNF signals via the Ras/ERK1/2 pathway (He et al. 2008) and Nodal acts through the SMAD2/3 and Pou5f1 pathway to stimulate the self-renewal of mouse SSCs (He et al. 2009). The GDNF/Ras signaling pathway in C18-4 cell line has been confirmed in mouse primary SSCs ( He et al. 2008, Lee et al. 2009).

\section{Immortalization of mouse type $A$ spermatogonial cell line $\mathbf{S} 4$ cells using Tert gene}

Since spermatogonial cell lines immortalized by SV large $T$ antigen gene prefer to proliferate rather than differentiate, Tert gene seems to be a more useful approach to establish spermatogonial cell lines for both proliferation and differentiation. In fact, the S4 mouse 
spermatogonial cell line has been developed by retrovirus vector containing mouse Tert (Feng et al. 2002). The S4 cells display the morphology and biochemical phenotype (e.g. Dazl, Pou5f1 and Kit) of mouse type A spermatogonia. Notably, this spermatogonial cell line can be coaxed by SCF to differentiate into spermatocytes and eventually haploid round spermatids in vitro (Feng et al. 2002). However, it remains unclear whether these spermatids have fertilization and developmental capacity.

Spermatogonia after immortalization with SV40 large $\mathrm{T}$ antigen or Tert can be cultured for a long period. Compared to the SV40 large T antigen method, Tert can immortalize cells without transformation or tumor formation (Morales et al. 1999). Spermatogonial cell lines immortalized with Tert not only proliferate and survive for a long period but also differentiate into spermatocytes and spermatids, which can be used to probe genetic and epigenetic regulation of spermatogenesis. Unfortunately, no human spermatogonial cell line immortalized by Tert is available now.

\section{The establishment and applications of spermatocyte lines}

We also illustrate the generation of rodent spermatocyte lines in Fig. 2, and their immortalization methods and phenotype are summarized in Table 2.

\section{Immortalization of spermatocytes using the SV40 large $T$ antigen}

The cell line GC-1spg has been characterized as a male germ cell line at a stage between type B spermatogonia and preleptotene spermatocytes (Hofmann et al. 1992). This cell line was established by transfection of SV40 large $\mathrm{T}$ antigen gene to all cell types in seminiferous tubule of 10-day-old mice, and it has been cultured successfully for 90 generations in 2.5 years. In morphology, GC-1 spg cells are larger than somatic cells in testis and have round nuclei with numerous clumps of chromatin, which corresponds to the characteristics of type B spermatogonia and preleptotene spermatocytes. In phenotype, synaptonemal complexes are undetected in the nuclei of GC-1spg cells, which usually appear in the leptotene or later spermatocytes (West et al. 2010). In addition, GC-1spg cells are positive for lactate dehydrogenase-C4 (LDHC4) isozyme, a marker specific for meiotic and postmeiotic germ cells (Liang et al. 1986); however, these cells are negative for phosphoglycerate kinase 2 (PGK2), which is normally expressed in secondary spermatocytes (McCarrey et al. 1996). Based on its morphological and biochemical features, GC-1spg cell line corresponds to the characteristics of cells between type B spermatogonia and preleptotene spermatocytes. This cell line can be used to examine mechanisms underlying the onset of meiosis of spermatocytes although it is unable to differentiate further in vitro.

\section{Spermatocyte lines immortalized with the SV40 large $T$ antigen gene and the gene coding for a temperature-sensitive mutant of p53}

The GC-2spd(ts) and GC-3spc(ts) cell lines were established from mouse preleptotene spermatocytes using an alternative strategy with the SV40 large T antigen and the gene coding for a temperature-sensitive mutant of p53 (Hofmann et al. 1994). Both cell lines express LDHC4 isozyme and Cytochrome ct isoform, hallmarks for spermatocytes. Wild-type p53 is able to abolish the initiation and maintenance of SV40 transformation (Fukasawa et al. 1991), and p53 protein is inhibited at the nonpermissive temperature of $39^{\circ} \mathrm{C}$, which allows SV40 large T antigen to exert its immortalization ability. The $p 53$ gene can be activated at the permissive temperatures of $37^{\circ} \mathrm{C}$ or $32^{\circ} \mathrm{C}$, which enables the cells to differentiate. Moreover, the GC-2spd line is able to generate cells with haploid DNA as well as morphological and phenotypic characteristics of round spermatids although the GC-3spc(ts) cell line cannot undergo meiosis. Therefore, the GC-2spd cell line has greater applications in uncovering the machinery underlying the differentiation of spermatocytes. Furthermore, using the GC-2spd line and the immortalized Sertoli cell lines, seminiferous tubules can be reconstituted in vitro, which could be used to identify novel autocrine and paracrine factors involved in meiosis and spermiogenesis. However, subsequent research is unable to confirm the original work by the same group (Wolkowicz et al. 1996) since LDHC4, Acr, Prm2 and haploid chromosome peak were undetected in GC-2spd line and it might be transformed. In addition, there is currently no human spermatocyte line immortalized by the SV40 large T gene and/or other genes.

\section{Spermatocyte line immortalized with a specific promoter-based selection strategy}

Another male germ cell line GC-4spc has been established from adult male transgenic mice, using a specific promoter-based selection method, i.e. the SV40 early promoter and a spermatocyte-specific promoter for human PGK2 (Tascou et al. 2000). Conventional method utilizing the oncogenes under the control of ubiquitous promoters might lead to contamination with other cells. In contrast, the promoter-based selection strategy can immortalize male germ cell lines at specific stages of spermatogenesis with unique promoters. The GC-4spc cell line has been identified as cells with the characteristics between those of preleptotene and early pachytene spermatocytes. This cell line has been cultured for a long period without morphological changes and can be transfected with other genes, and therefore it may be used to unveil the mechanisms of meiosis. 


\section{Applications and perspectives of male germ cell and Sertoli cell lines in basic studies and translation medicine}

As illustrated in Fig. 3, male germ cell and Sertoli cell lines can be utilized in basic studies as well as in reproductive and regenerative medicine. First of all, these cell lines can provide substantial sources of various kinds of male germ cells (spermatogonia and spermatocytes) and Sertoli cells. This makes it feasible to examine the genetic and epigenetic regulators in controlling the mitosis of spermatogonia and meiosis of spermatocytes. Specifically, these cell lines can be employed for investigating gene regulation, signaling transduction pathways, and non-coding RNA (e.g. microRNA and IncRNA) and DNA methylation in controlling the selfrenewal and differentiation of male germ cells (Yao et al. 2015). For example, using spermatogonial stem cell line C18-4, we have successfully demonstrated that Nodal plays an essential role in promoting the self-renewal of mouse SSCs via Smad2/3 pathway and Pou $5 f 1$ activation (He et al. 2009) and GDNF stimulates the proliferation and survival of mouse SSCs by activating Ras/ERK1/2 signaling pathway and transcription factor Fos (He et al. 2008). In addition, we have shown that miRNA-133b is uninvolved in the regulation of the human SSCs using a human SSC line (Hou et al. 2015) and it specifically enhances the proliferation of human Sertoli cells (Yao et al. 2016). Sertoli cell lines, e.g. SerW3 cell line and 93RS2 cell line, can be utilized to examine toxicology in male urinogenital system (Pognan et al. 1997) and develop new drugs for treating testicular tumor (Jiang et al. 1997) respectively. Sertoli cell lines contribute to the long-term culture of SSCs and 2- or 3-dimensional (3D) culture system to support the differentiation of SSCs into mature spermatids. Additionally, the G5, A31C4, C22A4 and C24A4 Sertoli cell lines can secret numerous growth factors, e.g. leukemia inhibitory factor (LIF), transforming growth factor- $\beta$ (TGF- $\beta$ ) and

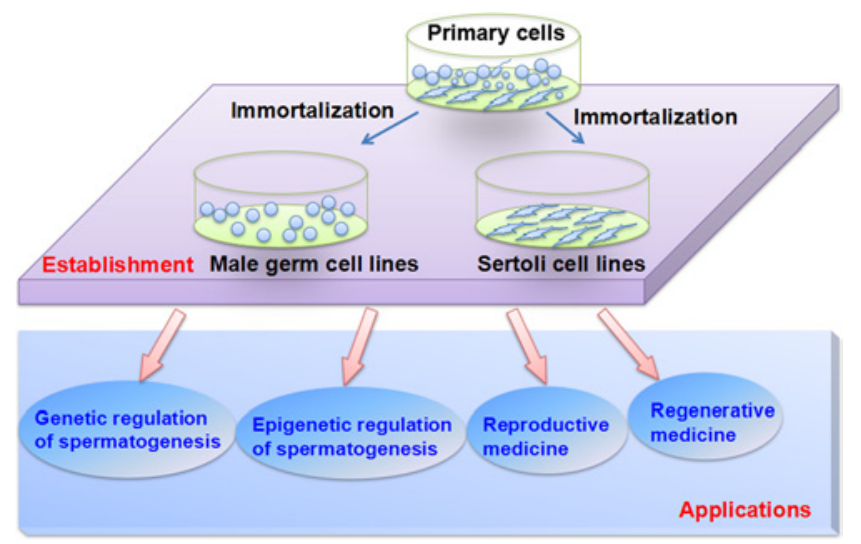

Figure 3 Schematic diagram illustrating the applications of male germ cell and Sertoli cell lines in basic studies and translation medicine.
bFGF (Hofmann et al. 2003, Sato et al. 2013), which are extremely important for the survival and proliferation of SSCs. Therefore, these Sertoli cell lines might be used as an excellent feeder layer for long-term culture and expansion of SSCs. When the SF7 Sertoli cell line is cocultured with Leydig cells and spermatocytes cell line GC-1spg, seminiferous tubules are formed (Hofmann et al. 1992). Therefore, it is practicable to coculture Sertoli cell and male germ cell lines with 3-D biomaterials or use Sertoli cell lines as feeder cells for 3-D culture of SSCs to reconstitute the testicular tissues (Kanatsu-Shinohara et al. 2012) and explore the precise process of testis formation in the near future. Sertoli cell lines could also be employed for 2-D and/or 3-D culture to generate mature and functional spermatids from SSCs (Sato et al. 2011) and ES cells (Zhou et al. 2016).

The establishment of male germ cell and Sertoli cell lines brings new promise for reproductive and regenerative medicine due to the great plasticity of spermatogonia and Sertoli cells. Human SSCs including spermatogonia can differentiate into male gametes (Yang et al. 2014a), dedifferentiate to pluripotent ES-like cells (Golestaneh, et al. 2009), and transdifferentiate to functional and mature hepatocytes (Chen et al. 2016). Therefore, they may bring inspirations for new therapeutic strategies to cure male infertility patients with spermatogonia and other human diseases (e.g. end-stage liver disease). The MSC-Ehl-Zs Sertoli cell line can produce insulin consistently (Kaur et al. 2014), which offers new opportunities for treating diabetes. Sertoli cells can also be reprogrammed to generate functional neurons (Sheng et al. 2012) and other cell lineages (e.g. Leydig cells and iPS cells) (Zhang et al. 2015) and thus they can have potential clinical value in translation medicine. Furthermore, these cell lines could be exploited to uncover the underlying etiology of male infertility (e.g. genetic factors and epigenetic errors) and perform drug toxicity screening for environmental chemicals and hormones.

\section{Summary}

In conclusion, we have discussed various kinds of approaches for establishing a number of male germ cell and Sertoli cell lines and addressed their phenotypic characteristics. Although immortalizing cell lines with virus (e.g. SV40 large T antigen) can enable cells to proliferate forever, it results in transformation and inability to differentiate. In comparison, immortalization with Tert can lead to both proliferation and differentiation of the cell lines, and thus they have advantages over the cell lines by SV40 large T antigen in uncovering the differentiation mechanisms of male germ cells. In addition, the establishment of male germ cell lines using their specific promoters could lead to unique types of cell lines. It is worth noting that the development of male germ cell and Sertoli cell lines 
could have important applications for clinic and research fields. We have recently established a human SSC line with an unlimited proliferation potential and no carcinogenesis, which could offer adequate human SSCs for both mechanistic studies and clinical applications. Nevertheless, other human cell lines for male germ cells and Sertoli cells are unavailable. Since there were distinct identity and phenotype of male germ cells and Sertoli cells between rodents and human ( $\mathrm{He}$ et al. 2010), it is essential to establish human testicular cell lines in order to better understand the mechanism of human spermatogenesis and develop therapeutic approaches to treat human diseases.

\section{Declaration of interest}

The authors declare that there is no conflict of interest that could be perceived as prejudicing the impartiality of the review reported.

\section{Funding}

This work was supported by key grants from the National Nature Science Foundation of China (31230048), the Chinese Ministry of Science and Technology (2014CB943101), the National Science Foundation of China (31171422, 31401250), the Program for Professor of Special Appointment (Eastern Scholar) at Shanghai Institutions of Higher Learning (2012.53), and Shanghai Municipal Education CommissionGaofeng Clinical Medicine Grant Support (20152511), and a key grant from the Science and Technology Commission of Shanghai Municipality (12JC1405900), and Key Discipline and Specialty Foundation of Shanghai Municipal Commission of Health and Family Planning.

\section{References}

Beverdam A, Wilhelm D \& Koopman P 2003 Molecular characterization of three gonad cell lines. Cytogenetic and Genome Research 101 242-249. (doi:10.1159/000074344)

Bourdon V, Lablack A, Abbe P, Segretain D \& Pointis G 1998 Characterization of a clonal Sertoli cell line using adult PyLT transgenic mice. Biology of Reproduction 58 591-599. (doi:10.1095/biolreprod58.2.591)

Blagosklonova O, Joanne C, Roux C, Bittard H, Fellmann F \& Bresson JL 2002 Absence of anti-Mullerian hormone (AMH) and M2A immunoreactivities in Sertoli cell-only syndrome and maturation arrest with and without AZF microdeletions. Human Reproduction 17 20622065. (doi:10.1093/humrep/17.8.2062)

Chen Z, Sun M, Yuan Q, Niu M, Yao C, Hou J, Wang H, Wen L, Liu Y, Li Z et al. 2016 Generation of functional hepatocytes from human spermatogonial stem cells. Oncotarget 7 8879-8895. (doi:10.18632/ oncotarget.7092)

Chuang CK, Lee KH, Fan CT \& Su YS 2007 FSH-sensitive murine sertoli cell lines immortalized by human telomerase gene hTERT express the androgen receptor in response to TNF-alpha stimulation. Bioscience Reports 27 403-411. (doi:10.1007/s10540-007-9063-y)

Dutertre M, Rey R, Porteu A, Josso N \& Picard JY 1997 A mouse Sertoli cell line expressing anti-Mullerian hormone and its type II receptor. Molecular and Cellular Endocrinology 136 57-65. (doi:10.1016/S03037207(97)00214-1)
Feng LX, Chen Y, Dettin L, Pera RA, Herr JC, Goldberg E \& Dym M 2002 Generation and in vitro differentiation of a spermatogonial cell line. Science 297 392-395. (doi:10.1126/science.1073162)

Fukasawa K, Sakoulas G, Pollack RE \& Chen S 1991 Excess wild-type p53 blocks initiation and maintenance of simian virus 40 transformation. Molecular and Cellular Biology 11 3472-3483. (doi:10.1128/ MCB.11.7.3472)

Golestaneh N, Kokkinaki M, Pant D, Jiang J, DeStefano D, FernandezBueno C, Rone JD, Haddad BR, Gallicano GI \& Dym M 2009 Pluripotent stem cells derived from adult human testes. Stem Cells and Devlopment 18 1115-1126. (doi:10.1089/scd.2008.0347)

Guan K, Nayernia K, Maier LS, Wagner S, Dressel R, Lee JH, Nolte J, Wolf F, Li M, Engel W et al. 2006 Pluripotency of spermatogonial stem cells from adult mouse testis. Nature 440 1199-1203. (doi:10.1038/ nature04697)

Guo Y, Hai Y, Yao C, Chen Z, Hou J, Li Z \& He Z 2015 Long-term culture and significant expansion of human Sertoli cells whilst maintaining stable global phenotype and AKT and SMAD1/5 activation. Cell Communication and Signaling 13 20. (doi:10.1186/s12964-015-0101-2)

Hai Y, Hou J, Liu Y, Yang H, Li Z \& He Z 2014 The roles and regulation of Sertoli cells in fate determinations of spermatogonial stem cells and spermatogenesis. Seminars in Cell \& Developmental Biology 29 66-75. (doi:10.1016/j.semcdb.2014.04.007)

He Z, Jiang J, Hofmann MC \& Dym M 2007 Gfra1 silencing in mouse spermatogonial stem cells results in their differentiation via the inactivation of RET tyrosine kinase. Biology of Reproduction 77 723733. (doi:10.1095/biolreprod.107.062513)

He Z, Jiang J, Kokkinaki M, Golestaneh N, Hofmann MC \& Dym M 2008 Gdnf upregulates c-Fos transcription via the Ras/Erk1/2 pathway to promote mouse spermatogonial stem cell proliferation. Stem Cells 26 266-278. (doi:10.1634/stemcells.2007-0436)

He Z, Jiang J, Kokkinaki M \& Dym M 2009 Nodal signaling via an autocrine pathway promotes proliferation of mouse spermatogonial stem/progenitor cells through Smad2/3 and Oct-4 activation. Stem Cells 27 2580-2590. (doi:10.1002/stem.v27:10)

He Z, Kokkinaki M, Jiang J, Dobrinski I \& Dym M 2010 Isolation, characterization, and culture of human spermatogonia. Biology of Reproduction 82 363-372. (doi:10.1095/biolreprod.109.078550)

Hofmann MC, Narisawa S, Hess RA \& Millan JL 1992 Immortalization of germ cells and somatic testicular cells using the SV40 large T antigen. Experimental Cell Research 201 417-435. (doi:10.1016/00144827(92)90291-F)

Hofmann MC, Hess RA, Goldberg E \& Millan JL 1994 Immortalized germ cells undergo meiosis in vitro. PNAS 91 5533-5537. (doi:10.1073/ pnas.91.12.5533)

Hofmann MC, Van Der Wee KS, Dargart JL, Dirami G, Dettin L \& Dym M 2003 Establishment and characterization of neonatal mouse sertoli cell lines. Journal of Andrololgy 24 120-130.

Hofmann MC, Braydich-Stolle L, Dettin L, Johnson E \& Dym M 2005 Immortalization of mouse germ line stem cells. Stem Cells 23 200-210. (doi:10.1634/stemcells.2003-0036)

Hou J, Niu M, Liu L, Zhu Z, Wang X Sun M, Yuan Q, Yang S, Zeng W, Liu Y et al. 2015 Establishment and characterization of human germline stem cell line with unlimited proliferation potentials and no tumor formation. Scientific Reports 5 16922. (doi:10.1038/srep16922)

Jiang C, Hall SJ \& Boekelheide K 1997 Development and characterization of a prepubertal rat Sertoli cell line, 93RS2. Journal of Andrology 18 393-399.

Kanatsu-Shinohara M, Inoue K, Lee J, Yoshimoto M, Ogonuki N, Miki H, Baba S, Kato T, Kazuki Y, Toyokuni S et al. 2004 Generation of pluripotent stem cells from neonatal mouse testis. Cell 119 1001-1012. (doi:10.1016/j.cell.2004.11.011)

Kanatsu-Shinohara M, Inoue K, Takashima S, Takehashi M, Ogonuki N, Morimoto H, Nagasawa T, Ogura A \& Shinohara T 2012 Reconstitution of mouse spermatogonial stem cell niches in culture. Cell Stem Cell 11 567-578. (doi:10.1016/j.stem.2012.06.011)

Katakura Y, Alam S \& Shirahata S 1998 Immortalization by gene transfection. Methods in Cell Biology 57 69-91. (doi:10.1016/S0091679X(08)61573-3)

Kaur G, Thompson LA, Pasham M, Tessanne K, Long CR \& Dufour JM 2014 Sustained expression of insulin by a genetically engineered sertoli 
cell line after allotransplantation in diabetic BALB/C mice. Biology of Reproduction 90 109. (doi:10.1095/biolreprod.113.115600)

Ko K, Tapia N, Wu G, Kim JB, Bravo MJ, Sasse P, Glaser T, Ruau D, Han DW, Greber B et al. 2009 Induction of pluripotency in adult unipotent germline stem cells. Cell Stem Cell 5 87-96. (doi:10.1016/j. stem.2009.05.025)

Konrad L, Munir Keilani M, Cordes A, Völck-Badouin E, Laible L, Albrecht M, Renneberg H \& Aumüller G 2005 Rat Sertoli cells express epithelial but also mesenchymal genes after immortalization with SV40. Biochimica et Biophysica Acta 1722 6-14. (doi:10.1016/j. bbagen.2004.10.015)

Lee J, Kanatsu-Shinohara M, Morimoto H, Kazuki Y, Takashima S, Oshimura M, Toyokuni S \& Shinohara T 2009 Genetic reconstruction of mouse spermatogonial stem cell self-renewal in vitro by Ras-cyclin D2 activation. Cell Stem Cell 5 76-86. (doi:10.1016/j.stem.2009.04.020)

Liang ZG, Shelton JA \& Goldberg E 1986 Non-cross-reactivity of antibodies to murine LDH-C4 with LDH-A4 and LDH-B4. Journal of Experimental Zoology 240 377-384. (doi:10.1002/(ISSN)1097-010X)

Mather JP 1980 Establishment and characterization of two distinct mouse testicular epithelial cell lines. Biology of Reproduction 23 243-252. (doi:10.1095/biolreprod23.1.243)

McCarrey JR, Kumari M, Aivaliotis MJ, Wang Z, Zhang P, Marshall F \& Vandeberg JL 1996 Analysis of the cDNA and encoded protein of the human testis-specific PGK-2 gene. Developmental Genetics $19321-$ 332. (doi:10.1002/(ISSN)1520-6408)

Morales CP, Holt SE, Ouellette M, Kaur KJ, Yan Y, Wilson KS, White MA, Wright WE \& Shay JW 1999 Absence of cancer-associated changes in human fibroblasts immortalized with telomerase. Nature Genetics 21 115-118. (doi:10.1038/5063)

Paquis-Flucklinger V, Michiels JF, Vidal F, Alquier C, Pointis G, Bourdon V, Cuzin F \& Rassoulzadegan M 1993 Expression in transgenic mice of the large T antigen of polyomavirus induces Sertoli cell tumours and allows the establishment of differentiated cell lines. Oncogene 8 2087-2094.

Pognan F, Masson MT, Lagelle F \& Charuel C 1997 Establishment of a rat Sertoli cell line that displays the morphological and some of the functional characteristics of the native cell. Cell Biology and Toxicology 13 453-463. (doi:10.1023/A:1007475928452)

Rassoulzadegan $M$, Paquis-Flucklinger V, Bertino B, Sage J, Jasin $M$, Miyagawa K, van Heyningen V, Besmer P \& Cuzin F 1993 Transmeiotic differentiation of male germ cells in culture. Cell 75 997-1006. (doi:10.1016/0092-8674(93)90543-Y)

Regadera J, Martinez-Garcia F, Gonzalez-Peramato P, Serrano A, Nistal M \& Suarez-Quian C 2001 Androgen receptor expression in sertoli cells as a function of seminiferous tubule maturation in the human cryptorchid testis. Journal of Clinical Endocrinology \& Metabolism 86 413-421.

Roberts KP, Banerjee PP, Tindall JW \& Zirkin BR 1995 Immortalization and characterization of a Sertoli cell line from the adult rat. Biology of Reproduction 53 1446-1453. (doi:10.1095/biolreprod53.6.1446)

Sato T, Katagiri K, Gohbara A, Inoue K, Ogonuki N, Ogura A, Kubota Y \& Ogawa T 2011 In vitro production of functional sperm in cultured neonatal mouse testes. Nature 471 504-507. (doi:10.1038/ nature09850)

Sato Y, Yoshida K, Nozawa S, Yoshiike M, Arai M, Otoi T \& Iwamoto T 2013 Establishment of adult mouse Sertoli cell lines by using the starvation method. Reproduction 145 505-516. (doi:10.1530/REP-12-0086)

Schlegel PN 2009 Evaluation of male infertility. Minerva Ginecologica 61 261-283.

Seandel M, James D, Shmelkov SV, Falciatori I, Kim J, Chavala S Scherr DS, Zhang F, Torres R, Gale NW et al. 2007 Generation of functional multipotent adult stem cells from GPR125+ germline progenitors. Nature 449 346-350. (doi:10.1038/nature06129)

Sette C, Dolci S, Geremia R \& Rossi P 2000 The role of stem cell factor and of alternative c-kit gene products in the establishment, maintenance and function of germ cells. International Journal of Developmental Biology 44 599-608.

Sharpe RM, McKinnell C, Kivlin C \& Fisher JS 2003 Proliferation and functional maturation of Sertoli cells, and their relevance to disorders of testis function in adulthood. Reproduction 125 769-784. (doi:10.1530/ rep.0.1250769)

Sheng C, Zheng Q, Wu J, Xu Z, Sang L, Wang L, Guo C, Zhu W, Tong M, Liu L et al. 2012 Direct reprogramming of Sertoli cells into multipotent neural stem cells by defined factors. Cell Research 22 208-218. (doi:10.1038/cr.2011.175)

Simon L, Ekman GC, Kostereva N, Zhang Z, Hess RA, Hofmann MC \& Cooke PS 2009 Direct transdifferentiation of stem/progenitor spermatogonia into reproductive and nonreproductive tissues of all germ layers. Stem Cells 27 1666-1675. (doi:10.1002/stem.v27:7)

Sneddon SF, Walther N \& Saunders PT 2005 Expression of androgen and estrogen receptors in sertoli cells: studies using the mouse SK11 cell line. Endocrinology 146 5304-5312. (doi:10.1210/en.2005-0914)

Sun H, Zhang G, Dong F, Wang F \& Cao W 2014 Reprogramming sertoli cells into pluripotent stem cells. Cell Reprogram 16 196-205. (doi:10.1089/cell.2013.0083)

Sze KL, Lee WM \& Lui WY 2008 Expression of CLMP, a novel tight junction protein, is mediated via the interaction of GATA with the Kruppel family proteins, KLF4 and Sp1, in mouse TM4 Sertoli cells. Journal of Cellular Physiology 214 334-344.

Tabuchi Y, Ohta S, Yanai N, Obinata M, Kondo T, Fuse H \& Asano S 2002 Development of the conditionally immortalized testicular Sertoli cell line TTE3 expressing Sertoli cell specific genes from mice transgenic for temperature sensitive simian virus 40 large $T$ antigen gene. Journal of Urology 167 1538-1545. (doi:10.1016/S0022-5347(05)65359-1)

Tabuchi Y, Takahashi R, Ueda M \& Obinata M 2003 Development of a conditionally immortalized testicular Sertoli cell line RTS3-3 from adult transgenic rats harboring temperature-sensitive simian virus 40 large T-antigen gene. Cell Structure and Function 28 87-95. (doi:10.1247/ csf.28.87)

Tascou S, Nayernia K, Samani A, Schmidtke J, Vogel T, Engel W \& Burfeind P 2000 Immortalization of murine male germ cells at a discrete stage of differentiation by a novel directed promoter-based selection strategy. Biology of Reproduction 63 1555-1561. (doi:10.1095/ biolreprod63.5.1555)

van Pelt AM, Roepers-Gajadien HL, Gademan IS, Creemers LB, de Rooij DG \& van Dissel-Emiliani FM 2002 Establishment of cell lines with rat spermatogonial stem cell characteristics. Endocrinology 143 1845-1850. (doi:10.1210/endo.143.5.8806)

Walther N, Jansen M, Ergun S, Kascheike B \& Ivell R 1996 Sertoli cell lines established from $\mathrm{H}-2 \mathrm{~Kb}$-tsA58 transgenic mice differentially regulate the expression of cell-specific genes. Experimental Cell Research 225 411-421. (doi:10.1006/excr.1996.0192)

Wang X, Qin J, Zhao RC \& Zenke M 2014 Reduced immunogenicity of induced pluripotent stem cells derived from Sertoli cells. PLOS ONE $\mathbf{9}$ e106110. (doi:10.1371/journal.pone.0106110)

West FD, Roche-Rios MI, Abraham S, Rao RR, Natrajan MS, Bacanamwo M \& Stice SL 2010 KIT ligand and bone morphogenetic protein signaling enhances human embryonic stem cell to germ-like cell differentiation. Human Reproduction 25 168-178. (doi:10.1093/ humrep/dep338)

Wolkowicz MJ, Coonrod SA, Reddi PP, Millan JL, Hofmann MC \& Herr JC 1996 Refinement of the differentiated phenotype of the spermatogenic cell line GC-2spd(ts). Biology of Reproduction 55 923-932. (doi:10.1095/ biolreprod55.4.923)

Wosnitzer M, Goldstein M \& Hardy MP 2014 Review of Azoospermia. Spermatogenesis 4 e28218.

Wu L, Dong H, Zhao J, Wang Y, Yang Q, Jia C \& Ma J 2015 Diosgenin stimulates rat TM4 cell proliferation through activating plasma membrane translocation and transcriptional activity of estrogen receptors. Biology of Reproduction 92 24. (doi:10.1095/biolreprod.114.124206)

Yang S, Ping P, Ma M, Li P, Tian R, Yang H, Liu Y, Gong $Y$, Zhang Z, Li Z et al. 2014a Generation of haploid spermatids with fertilization and development capacity from human spermatogonial stem cells of cryptorchid patients. Stem Cell Reports 3 663-675. (doi:10.1016/j. stemcr.2014.08.004)

Yang L, Wang Y, Zhang Q, Lai Y, Li C, Huang W, Duan Y, Jiang Z, Li X, Cai Z et al. $2014 b$ Identification of Hsf1 as a novel androgen receptorregulated gene in mouse Sertoli cells. Molecular Reproduction and Development 81 514-523. (doi:10.1002/mrd.22318)

Yang H, Liu Y, Hai Y, Guo Y, Yang S, Li Z, Gao WQ \& He Z 2015 Efficient Conversion of spermatogonial stem cells to phenotypic and functional dopaminergic neurons via the PI3K/Akt and P21/Smurf2/Nolz1 pathway. Molecular Neurobiology 52 1654-1669. (doi:10.1007/s12035-0148966-4) 
Yao C, Liu Y, Sun M, Niu M, Yuan Q, Hai Y, Guo Y, Chen Z, Hou J \& He Z 2015 MicroRNAs and DNA methylation as epigenetic regulators of mitosis, meiosis and spermiogenesis. Reproduction 150 R25-R34. (doi:10.1530/REP-14-0643)

Yao C, Sun M, Yuan Q, Niu M, Chen Z, Hou J, Wang H, Wen L, Liu Y, Li Z et al. 2016 MiRNA-133b promotes the proliferation of human Sertoli cells through targeting GLI3. Oncotarget 7 2201-2219. (doi:10.18632/ oncotarget.6876)

Zhang Z, Gong Y, Guo Y, Hai Y, Yang H, Yang S, Liu Y, Ma M, Liu L, Li Z et al. 2013 Direct transdifferentiation of spermatogonial stem cells to morphological, phenotypic and functional hepatocyte-like cells via the ERK1/2 and Smad2/3 signaling pathways and the inactivation of cyclin A, cyclin B and cyclin E. Cell Communication and Signaling 1167. (doi:10.1186/1478-811X-11-67)
Zhang L, Chen M, Wen Q, Li Y, Wang Y, Qin Y, Qin Y, Cui X, Yang L, Huff V et al. 2015 Reprogramming of Sertoli cells to fetal-like Leydig cells by Wt1 ablation. PNAS 112 4003-4008. (doi:10.1073/pnas.1422371112)

Zhou Q, Wang M, Yuan Y, Wang XP, Fu R, Wan HF, Xie MM, Liu MX, Guo XJ, Zheng Y et al. 2016 Complete meiosis from embryonic stem cell-derived germ cells in vitro. Cell Stem Cell 18 330-340. (doi:10.1016/ j.stem.2016.01.017)

Received 17 November 2015

First decision 4 January 2016

Revised manuscript received 1 April 2016

Accepted 8 April 2016 